Joseph M. Spencer*

\title{
Badiou and Frege: A Continental Critique of Logical Form
}

https://doi.org/10.1515/opphil-2018-0008

Received June 6, 2018; accepted July 31, 2018

\begin{abstract}
Various critiques of important (early) analytic thinkers made by Alain Badiou in the late 1960s have been largely overlooked by continental philosophers and entirely overlooked by analytic philosophers. This paper looks in detail at Badiou's 1969 essay "Mark and Lack," providing an exposition and clarification of his direct and sustained critique of Gottlob Frege's supposed ideological (rather than scientific) philosophical commitments. Badiou's intellectual context is analyzed in some detail, not only explaining his theoretical debt to his then-master Louis Althusser, but also clarifying his understandings of the notions of "the scientific" and "the ideological" in light of the projects of Gaston Bachelard and Georges Canguilhem. A philosophical exposition of Badiou's point-by-point critique of Frege's conception of logic follows. Finally, the paper concludes with an analysis of the more general relevance of Badiou's half-century-old critiques in light of developments in contemporary analytic metaphysics, especially those indebted to W. V. O. Quine and Donald Davidson. In essence, Davidson's Fregean reconfiguration of Tarski's work on truth (more explicit than, but not unrelated to, Quine's work) places contemporary analytic metaphysics within the scope of what Badiou directly criticizes. It is suggested that Badiou's critique find a place in discussions of analytic metaphysics.
\end{abstract}

Keywords: Gottlob Frege; Alain Badiou; Donald Davidson; Alfred Tarski; ideology; philosophy of science; analytic metaphysics; analytic-continental dialogue; Gaston Bachelard; Georges Canguilhem

Before political events during the late 1960s and early 1970s transformed Alain Badiou from an intellectual into an activist, his philosophical work focused primarily on diagnosing what he took to be the ideological commitments of analytic philosophy. Unfortunately, because Badiou has only come to be known in English-speaking countries quite recently, and because what has come to be known best in these countries is Badiou's mature work (produced long after he had largely abandoned his early debate with analytic thought), these early attempts to address in some way the divide between analytic and continental philosophy have been largely ignored. ${ }^{1}$ In this paper, I mean to undertake a preliminary assessment of Badiou's potential philosophical contribution to analytic-continental dialogue from this very early stage in his career. My aim is therefore in part expository and corrective, calling attention to and clarifying Badiou's early, generally ignored interest in addressing analytic thought. In addition, however, I wish to outline a provisional argument that Badiou's arguments are potentially relevant to continuing interests in the analytic tradition and not only to the early analytic thinkers he has explicitly engaged. Badiou should, therefore, be of interest for thinkers like W. V. O. Quine, Donald Davidson, and their heirs.

1 It is common to demarcate the boundary between Badiou's early writings and his mature writings by taking Theory of the Subject as his first mature work. His earliest writings are few, and the 1970s were largely given to more strictly political activity. The real culmination of his work came, of course, with Being and Event and, so far, its only strict sequel, Logics of Worlds. (For some discussion of periodization in Badiou's work, see Hallward, Badiou, 29-47; and, more generally, Bosteels, Badiou and Politics.) Unfortunately for the analytic-continental dialogue, there runs concurrent with the maturation of Badiou's project an increasingly dismissive and uncharitable attitude on his part toward the analytic tradition. See caricatures, for example, in Badiou, Conditions, 9; Badiou, Infinite Thought, 43-44; and, very recently, Badiou and Haéri, In Praise of Mathematics, 13.

\footnotetext{
*Corresponding author: Joseph M. Spencer, Brigham Young University, Provo, United States of America;

E-mail: joseph_spencer@byu.edu
} 
To keep my exposition focused, however, I largely limit myself here to commenting on what Badiou says about just one (proto-)analytic philosopher in particular: Gottlob Frege. For this reason, I generally keep my sights trained on Badiou's 1969 essay "Mark and Lack," although I draw, where useful and relevant, on others among Badiou's publications in the late 1960s. (I do not comment here on Badiou's discussion of Frege in his 1990 Number and Numbers, written in the context of the first full maturation of the Badiouian enterprise. ${ }^{2}$ Not only does this later discussion of Frege hail from a substantially different stage in the development of Badiou's thought, it reproduces Badiou's decades-earlier interpretation of Frege in most details.) I therefore proceed as follows. In a first section ("Context"), I explain the roots and orientation of Badiou's early project, setting it preliminarily in context with respect to the work and influence of Louis Althusser. In a second section ("Critique"), I provide an exposition of Badiou's critique of Frege in "Mark and Lack." Finally, in a third section ("Consequence"), I provide some comment on Badiou's critique and sketch its potential interest for contemporary analytic thought.

\section{Context}

In the mid-60s, Badiou unquestionably remained under the influence of his former teacher, Louis Althusser, as many commenters-and Badiou himself-have often noted. ${ }^{3}$ As is apparent from his writings, Althusser was much less committed than his student was to engaging seriously with analytic philosophy (and, more generally, with the formal sciences that drew the attention of early analytic thinkers). Tellingly, the most frequent (if not the only) assessments of analytic thought to be found in Althusser's extant writings are passing affirmations that Lenin's criticisms of Ernst Mach in Materialism and Empirio-Criticism somehow suffice to dispense more or less entirely with analytic philosophy. ${ }^{4}$ But even as Badiou was obviously more interested in taking analytic thought seriously than was his master, his approach to the task was strongly oriented by Althusser's larger project, which defined philosophy as the work of drawing lines of demarcation between science and its (inevitable) ideological recapture. Attempting to defend and to solidify the role played in the French Communist Party by philosophers and intellectuals, Althusser famously argued that "philosophy represents politics in the domain of theory or, to be more precise: with the sciences-and, vice versa, philosophy represents scientificity in politics, with the classes engaged in the class struggle." His basic (Leninist) idea was that spontaneous ideological associations held by those at work within the sciences always compromise the actual practice of science. Philosophers associated with the Left therefore take upon themselves the task of extracting the material products of scientific work from the ideological muddle of its concrete expression. In this sense, “the scientific' and 'the ideological' are philosophical categories and the contradictory couple they form is brought to light by philosophy: it is philosophical."”

All this Badiou took over directly into his own work in the second half of the 1960s. His most substantial publication during the period was a small book, The Concept of Model, which in fact originated as a

2 See Badiou, Number and Numbers, 16-30.

3 See throughout Bosteels, Badiou and Politics; as well as Pluth, Badiou, 1-28. For Badiou's own comments on his relationship to Althusser, written from the perspective of his mature work, see Badiou, Metapolitics, 58-67; and Badiou, Pocket Pantheon, 54-89.

4 See, for instance, scattered references in Althusser, "Philosophy and the Spontaneous Philosophy of the Scientists". See also Althusser's direct confession of sorts in Althusser, The Future Lasts Forever, 176: "I myself was ignorant [in the 1960s] about everyone, including Carnap, Russell, Frege, and therefore about logical positivism, as well as about Wittgenstein and English analytical philosophy."

5 Althusser, "Philosophy and the Spontaneous Philosophy of the Scientists", 199. For helpful context, see Lewis, Louis Althusser and the Traditions of French Marxism.

6 Althusser, "Philosophy and the Spontaneous Philosophy of the Scientists", 107. The particular concern that drew Althusser's attention in this direction was the resurgence of a kind of humanist Hegelianism in French Marxist circles, which he regarded as an ideological obfuscation of the scientific nature of Marx's thought. See, in this regard, especially Althusser, For Marx. For Althusser's most classic exposition of ideology, see Althusser, On the Reproduction of Capitalism. 
contribution to a public "Philosophy Course for Scientists" organized by Althusser. ${ }^{7}$ There Badiou displayed his Althusserian bona fides by defining philosophy as "the ideological recovery of science.” Distinguishing scientific concepts from ideological notions, he set out in this short book to draw a line of demarcation between 'two epistemological instances of the word 'model.' One is a descriptive notion of scientific activity [ideological]; the other is a concept of mathematical logic [scientific]." In a similar gesture in a review essay from 1967, Badiou went on record as saying that Althusser's project marked the "(re)commencement of dialectical materialism." ${ }^{9}$ That this same general strategy defines Badiou's late-60s reflections on Frege is clear from the very first line of his study on the subject: "Epistemology breaks away from ideological recapture, in which every science comes to mime its own reflection, insofar as it excludes that recapture's institutional operator, the notion of Truth." ${ }^{10}$ Here, as elsewhere in his work from the time, Badiou aims to distinguish the genuinely scientific elements in and around the analytic movement from what he takes to be ideological deviations represented within the work of analytic thinkers.

Before turning directly to Badiou's essay on Frege and its specific origins, it is worth noting that his general (Althusserian) project in the 1960s broadly followed the same spirit that animated many of the earliest analytic philosophers, especially those associated with the so-called Vienna Circle. In the "manifesto" of sorts that originated from the Vienna Circle, for instance, Hans Hahn, Otto Neurath, and Rudolf Carnap championed "anti-metaphysical factual research" and the associated "spirit of a scientific conception of the world," over against "metaphysical and theologizing thought." "For such thinkers as for Badiou, moreover, science took one of its surest shapes in mathematical logic. And, significantly, the battle against ideology was for both parties motivated (to a lesser or a greater degree) by a conviction that Marx (among others) represented a breakthrough in scientific reflection on political economy. Naturally, Badiou's assessments as to where one finds science and where one finds ideology were different from those made by early analytic philosophers. The difference in viewpoints is clear especially when Badiou in The Concept of Model takes Carnap as a key example of analytic thought as ideologically compromised. ${ }^{12}$ Carnap is of course arguably the analytic philosopher who most famously strove to distinguish the genuinely scientific from the merely metaphysical, targeting Martin Heidegger as a thinker who exemplarily errs in metaphysical speculation. ${ }^{13}$ Thus, although the projects represented by Badiou and key representatives of early analytic philosophy share broad similarities, what draws interest here is the specific set of differences that separate them. And more illustrative than Badiou's critique of Carnap, ${ }^{14}$ in the end, is his analysis of Frege, of the figure who arguably laid the foundations of the analytic project. ${ }^{15}$

7 A basic outline of the course-which was interrupted in the midst of Badiou's own contributions by the events of May 1968can be found in Althusser, "Philosophy and the Spontaneous Philosophy of the Scientists", xiv. Other contributors (apart from Althusser and Badiou) were Pierre Macherey, Etienne Balibar, François Regnault, Michel Pêcheux, and Michel Fichant.

8 Badiou, The Concept of Model, 9.

9 See Badiou, “The (Re)commencement of Dialectical Materialism.” Badiou's relationship to Althusser of course changed drastically in subsequent years. For an important articulation of a whole generation's dawning dissatisfaction with Althusser after May 1968, see Rancière, Althusser's Lesson; and for some general historical context, see the sometimes problematic Wolin, The Wind from the East.

10 Badiou, "Mark and Lack," 159.

11 Hahn, Neurath, and Carnap, "Wissenschaftliche Weltauffassung: Der Wiener Kreis [The Scientific Conception of the World: The Vienna Circle]," 301.

12 For Badiou's critique of Carnap, see, generally, Badiou, The Concept of Model.

13 For Carnap's most widely read critique of metaphysics in philosophy, see, of course, Carnap, "The Elimination of Metaphysics Through Logical Analysis of Language.”

14 Carnap's later thought, especially as this came to be recognized as similar to the thought of Thomas Kuhn, arguably approaches Badiou's thought from another angle, with interest in the epistemological implications of historical breaks in the history of science. See Earman, “Carnap, Kuhn, and the Philosophy of Scientific Methodology.”

15 Such is the argument of Michael Dummett in his Origins of Analytical Philosophy. More recently, Scott Soames, in his Philosophical Analysis in the Twentieth Century, feels the need to apologize for largely eliminating Frege from his account. In his brilliant What Is Analytic Philosophy?, Hans-Johann Glock nicely describes Frege's project as marking the "first glimmerings" of the analytic project. 
The specific occasion for Badiou's 1960s critique of Frege was an essay by Jacques-Alain Miller, to which Badiou's essay served as a response. ${ }^{16}$ Miller essentially argues in his essay that Frege's famous account of number from The Foundations of Arithmetic provides a formal analog for the concept of the human or speaking subject worked out in the writings of Sigmund Freud and later developed in the seminars of Jacques Lacan. More specifically, Miller seeks to provide an account of what he calls "suture," namely, "the relation of the subject to the chain of its discourse" or "the general relation of lack [the Freudian subject as a kind of meaningless void in the midst of otherwise meaningful discourse] to structure [assumed in the Freudian notion of discourse as meaningfully ordered around the meaningless void of the unspeakable]."17 These two features of the Freudian-Lacanian sketch of the speaking subject Miller maps onto Frege's two fundamental moves in laying the foundations of arithmetic. First, Frege famously establishes the definition of the number 0 "on purely logical grounds": " 0 is the Number which belongs to the concept "not identical with itself."” ${ }^{18}$ He then establishes a well-defined successor function that allows the whole number series to be derived from operations performed on the defined number 0: "there exists a concept $F$, and an object falling under it $x$, such that the Number which belongs to the concept $F$ is $n$ and the Number which belongs to the concept "falling under $F$ but not identical with $x$ is $m . "{ }^{19}$ As Freud generally and Lacan formally defines the complex structure of the speaking subject, Frege defines number in terms of a foundational lack or void (the number 0 ) and an enchaining or repetition function that sutures the discernibly structured onto that foundational lack or void (the successor function). ${ }^{20}$

This general parallel interests Miller, but what perhaps especially draws him to set Freud-Lacan side by side with Frege is a further and more particular (potential) parallel. In Leibniz's definition of identity, in which Frege finds the "purely logical grounds" needed to define 0, there is assumed a conception of truth and its relation to meaning that suggests a core Lacanian thesis. Leibniz's definition is this: "Things are the same as each other, of which one can be substituted for the other without loss of truth." ${ }^{21}$ Miller comments: "Truth is recovered [from the possibility of its loss] because the substituted thing, in that it is identical with itself, can be the object of a judgment and enter into the order of discourse: identical with itself, it can be articulated. But that a thing should not be identical with itself subverts the field of truth, ruins it and abolishes it. ... Identity-with-itself is essential if truth is to be saved."22 On Miller's reading, truth is secured by a certain "passage from the thing to the object," the latter imaginarily self-identical and ready to be addressed by a subject that fails to understand itself. ${ }^{23}$ There is thus an entanglement of truth and meaning at the base of Frege's conception of arithmetic, just as there is such an entanglement of truth and meaning at the base of the speaking subject's ordered discourse, as this was understood by Freud and especially Lacan.

Badiou in his essay does not disagree with Miller's basic analysis of the relations among lack, succession, meaning, and truth in Frege. But what draws Badiou's attention to Frege is not the possible

16 Both essays appeared in the short-lived but important journal Cahiers pour l'analyse, major highlights of and commentaries on which appear in Hallward and Peden, Concept and Form. Miller’s essay, "Suture," appears there.

17 Miller, "Suture," 93.

18 Frege, The Foundations of Arithmetic, 87-88.

19 Ibid., 89. These definitions of course depend heavily on philosophical work accomplished earlier in Frege's book. See the establishment of a general philosophical definition of number in Frege, The Foundations of Arithmetic, 58-62.

20 For a general introduction of sorts to the Freudian-Lacanian conception of the subject, see the helpful introduction, Fink, The Lacanian Subject.

21 Frege, The Foundations of Arithmetic, 76.

22 Miller, "Suture," 96.

23 Ibid. This conception of objects as the only things with which (standard) human subjects concern themselves-although I use here the stylistic phrasing of continental philosophy-is relatively standard in analytic metaphysics. Francesco Berto and Matteo Plebani, for instance, trace this (essentially Quinean) view directly back to Frege themselves. See Berto and Plebani, Ontology and Metaontology, 41-47. What Miller here calls "the thing” is roughly equivalent to what William James famously called the "great blooming, buzzing confusion" before or apart from the categories deployed by normal human subjects. James, The Principles of Psychology, 1:488. 
parallel between Frege's notion of number and the Freudian-Lacanian conception of the subject. ${ }^{24}$ It is, rather, the possibility of drawing a line of demarcation between ideology and science in and around Frege's work-especially in light of Frege's foundational role for the whole scientific project of mathematics in the twentieth century. Badiou finds in Frege (as in Carnap and other early analytics) a tendency to "partition the discourse of science according to a presupposed distinction between empirical reality and theoretical form"-specifically by finding in the "classic distinction" between syntax and semantics a "redoubling" of "the inaugural couple of formal and empirical science." 25 This Badiou apparently regarded at the time as a common ideological gesture in analytic philosophy, to misappropriate the relation between syntax and semantics and to misconstrue the dialectical materialist underpinnings of science. According to Badiou, Frege makes this ideological move more subtly and perhaps more instructively than many of his philosophical descendants. The details are worth investigating closely.

\section{Critique}

In the course of his treatment of Frege, Badiou first sketches just an outline of what he regards as the fully scientific conception of mathematical logic (which he then opposes to Frege's conception). ${ }^{26}$ This fully scientific conception deserves attentive exposition if the critique of Frege is to make real sense. According to Badiou, the scientific conception of logic requires a "triple articulation of the logical process." ${ }^{27}$ That is, logic entails the "production of a division in linear writing" which unfolds over the course of three "mechanisms," namely, "concatenation, formation, and derivation." 28 Every ideological obfuscation of the strict science of logic will involve some obscuring of the relationships among these mechanisms, or some addition to them of a fourth and problematic mechanism. Badiou highlights the need especially to keep the second of the three mechanisms clear: "Any occlusion of the autonomy of the second mechanism ... entails losing the very essence, i.e. the productive function, of the logical process." 29

Prior to the operation of any of the three mechanisms, Badiou assumes the existence only of writing, "a stock of graphic marks," which form "the absolutely primary raw material of the logical process."30 These form, in essence, the domain for the first mechanism. The first mechanism, then, the mechanism of concatenation (M1), performs the simple operation of receiving graphic marks and composing from them all possible finite sequences of marks. These finite sequences of marks then form the domain for the second mechanism, the mechanism of formation (M2). This second mechanism then operate with a set of rules ("rules of formation," "the syntax") that determines which finite sequences of marks are well-formed and which not, imposing what Badiou calls a "perfect dichotomy," "without remainder," on the domain of sequences provided to it by M1. ${ }^{31} \mathrm{M} 2$ therefore produces a definite set of well-formed finite sequences of graphic marks that effectively forms the domain for the third and final mechanism. This, finally, the mechanism of derivation (M3), has a double function. It "is set up to produce: (1) a perfect dichotomy between Theses (or derivable statements) and non-Theses (non-derivable statements); (2) a certain type of functional relation between these two divided halves." ${ }^{32}$ It should be noted that it is not enough for M3

24 Badiou has more recently arrayed his mature work directly and consistently against the Lacanian project. This is already clear in Theory of the Subject, but the way that both Being and Event and Logics of Worlds work their way ultimately toward direct confrontations of Lacan's theses seems still more significant. See Badiou, Being and Event, 431-35; and Badiou, Logics of Worlds, 477-82. See also the set of essays in Badiou, Conditions, 201-84; and two recent debates of sorts: Badiou and Roudinesco, Jacques Lacan, Past and Present; and Badiou, "Formulas of L'Étourdit.”

25 Badiou, The Concept of Model, 19.

26 In parallel, Badiou offers in full what he regards as the wholly scientific conception of models in the course of his critique of Carnap in Badiou, The Concept of Model, 23-41.

27 Badiou, "Mark and Lack," 160.

28 Ibid.

29 Ibid., 160-61.

30 Ibid., 161.

31 Ibid., 161-62.

32 Ibid., 162. 
just to impose a further perfect dichotomy (of the derivable and the non-derivable) on the already perfectly dichotomized product of M2 (the well-formed and the ill-formed). That is, the purpose of M3 is not just to decide what well-formed statements can and cannot be derived within the rules of the system. It is necessary also to introduce "an operator ... such that if a statement belongs to one division [either the derivable or the non-derivable], then the statement obtained by applying to it the operator ... will be in the other division [either the non-derivable or the derivable]." ${ }^{33}$ As Badiou summarily puts this point, "What is originally at issue [in M3] is not the cut as such, but a function relating the separated halves" of the derivable and the non-derivable. ${ }^{34}$

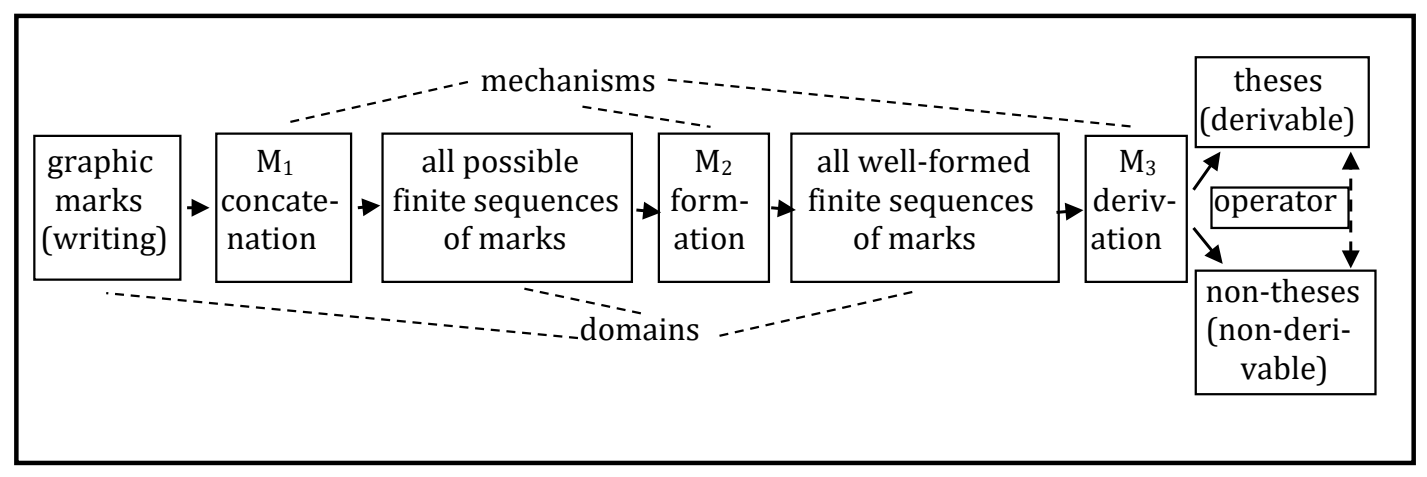

The operator that completes $M_{3}$ is, of course, the one classically understood as negation (graphically, $\sim .^{35}$ The necessity of introducing this operator into logic is something Frege had already himself established, ${ }^{36}$ and he clearly intended it to perform the function to which Badiou assigns it-namely, that of mapping the derivable to the non-derivable and the non-derivable to the derivable. ${ }^{37}$ On certain accounts (including Badiou's, as will be seen), it is just here that Frege ran into philosophical trouble. ${ }^{38}$ At any rate, Frege's successors-chiefly and most famously Kurt Gödel and Alfred Tarski-would go on to show that real difficulties come with the operator in question. Badiou summarizes these crucial difficulties in the following terms: "One might hope to expel from $T$ (the set of derivable statements) all the relations $t \ldots \sim t$; otherwise, the system would be inconsistent. But one can then go on to show that some of these relations will always remain in NT [the set of non-derivable statements]: precisely those which concern undecidable statements." ${ }^{39}$ This, of course, is just Badiou's statement of Gödel's famous incompleteness theorem. Within a syntax strong enough to produce the basic statements of arithmetic, it is impossible to identify an operator that maps one to one all derivable and non-derivable statements; the operator in question will always map at least one non-derivable statement to another (or, endangering consistency, it will map at least one derivable statement to another). Because this operator therefore does not correspond to any clear delineation of the opposition between the system's derivable and non-derivable statements, even as $M_{3}$ unmistakably distinguishes derivable and non-derivable statements, Badiou offers the following striking formulation: "There exists at some point, between the parts $\mathrm{T}$ and NT, a distance without concept." 40

It is the "distance without concept" between the derivable and the non-derivable in every (consistent) syntactical structure (with the ability or produce the basic statements of arithmetic) that calls for the

33 Ibid., 163.

34 Ibid.

35 As elsewhere, of course, Badiou reminds his readers that "the intuitive meaning ... is an obstacle here." Badiou, "Mark and Lack," 163.

36 See Frege, The Basic Laws of Arithmetic, 40-42.

37 Ibid., 39. Bertrand Russell, following a suggestion by Jean Nicod, explores the possibility of eliminating negation from logic by using the so-called Sheffer stroke. The relevance of this suggestion to Badiou's conception of logic is unclear. See Russell, “The Philosophy of Logical Atomism," 210-11.

38 See Dummett, “Truth”; as well as the helpful commentary in Milne, "Frege's Folly.” For the chief attempt to save Frege from the relevant difficulty, see Weiner, Frege in Perspective.

39 Badiou, "Mark and Lack," 163-64.

40 Ibid., 164. 
development of so many semantic models of structure. The work of logical structure or syntax ends with the production of the unintelligibly distinct sets of derivable and non-derivable statements, but it is possible to produce a variety of models of a given logical structure or syntax in which the "truth" or "falsity" of some undecidable statement is decided. ${ }^{41}$ And close investigation of these models in turn reveals much about the logical structure for which they serve as models..$^{42}$ The work of the model theorist lies here, in exploring the tight relationships among appropriate semantic models for a given syntax, with such exploration consistently predicated on the strictly intra-mathematical relationship between syntax and semantics. (In essence, the larger network of models for a particular syntax together reveal something like the virtual map of the syntax in question.) This is, as Badiou summarily argues, the scientific notion of logic, the very "methodology of deductive sciences," as Alfred Tarski calls it in the subtitle to his introductory textbook on model theory..$^{43}$ And any philosophical use of the concept of model-of the syntax-semantics relation-that ignores its strictly scientific bearings Badiou will call ideological.

What Badiou means by the "scientific" here seems at first to be obscure, and it is time to become clearer about what he understands by "science" (and at least preliminarily clearer about what he understands by “ideology"). Helpfully, Badiou clarifies his meaning elsewhere in his work from the late 1960s. He insists, for instance, in The Concept of Model that "to speak of 'Science' is an ideological symptom" because science is multiple. ${ }^{44} \mathrm{He}$ therefore speaks instead there of "scientific activity" and "scientific practice," or at times of "an experimentalist conception of science," relying heavily on the theoretical framing provided by French philosophers of science Gaston Bachelard and Georges Canguilhem. Bachelard is a readier source for the conception of scientific activity Badiou has in mind, if only because Badiou and Canguilhem alike rely on him, and because Bachelard shares Badiou's interest in the exact sciences..$^{45}$ From the outset of The New Scientific Spirit (as throughout his writings), Bachelard points to "two fundamental philosophical attitudes" that, although they are generally regarded as philosophically opposed or contradictory, nonetheless "coexist ... p peacefully in the modern scientific mind: rationalism and realism." ${ }^{46}$ Scientific practice effectively cancels the polarity that keeps these two philosophical attitudes at a distance, and so Bachelard argues that the task of philosophy of science is to make clear that and how scientific practice enacts a "realization of the rational." ${ }^{47}$ The concrete example to which Bachelard often turns his attention is the requisite use, in scientific activity, of scientific instruments. These, he classically argues, are "nothing

41 The words "truth" and "falsity" are placed in quotation marks to signal the fact that these must not here be understood according to any robust philosophical-whether metaphysical or epistemological-conception. These do not (necessarily) align with the notions of truth or falsity, and any decisions in advance that they might do so usually leads to philosophical error. For this reason, Badiou elsewhere replaces the terms "vrai" ("true") and "faux" ("false") with "vri" and "fax" as he constructs an appropriate syntax for mathematical logic. See Badiou, The Concept of Model, 30.

42 This is the subject of my recent dissertation, which considers the uses of model theory in Badiou and Tarski, attempting to derive from their similarities and differences a general conception of the philosophical significance of this development in the history of mathematical logic. See Spencer, "Formalism and the Notion of Truth."

43 See Tarski, Introduction to Logic and to the Methodology of Deductive Sciences.

44 Badiou, The Concept of Model, 7. Naturally, Badiou cites on this occasion Althusser's own contribution to the "Course on Philosophy for Scientists.”

45 Badiou cites Canguilhem, Knowledge of Life, 3-24. Badiou has occasionally been taken to task for his apparent lack of interest in the biological sciences. See, especially, Johnston, Prolegomena to Any Future Materialism, Volume One, 81-107. For some few comments from Badiou on biological concerns, see Badiou, The Subject of Change. I might note myself that Johnston's critique of Badiou on this point insists that Badiou's relationship to the sciences is hampered by dependence on Alexandre Koyré, although it seems clearer that Badiou's interests in the philosophy of science have more to do with Bachelard and Canguilhem-not to mention his ongoing polemic against Gilles Deleuze-all of which suggests a more complicated picture than that assumed by Johnston.

46 Bachelard, The New Scientific Spirit, 1. Incidentally, it is this work that Badiou specifically cites in The Concept of Model (and not, as the editor of the English text erroneously states, Bachelard's equally important book, The Formation of the Scientific Mind). See Badiou, The Concept of Model, 15.

47 Bachelard, The New Scientific Spirit, 4. Bachelard's most interesting development of this thesis, in my view, is to be found in Bachelard, Les intuitions atomostiques, where he distinguishes modern science and its philosophical bearings by contrast with the larger history of (supposed) scientific materialism undertaken in the name of atomism. 
but theories materialized." ${ }^{48}$ This it clearly what orients Badiou's critique of Rudolf Carnap in The Concept of Model. In the very first sentence of that work, Badiou identifies as a key "ideological formation" the philosophical view that begins from "a presupposed distinction between empirical reality and theoretical form." And he states: "this is exactly how logical positivism, the dominant epistemology of Anglo-Saxon countries for more than twenty years," approaches science. He of course cites, by way of illustration, Carnap's "Logical Foundations of the Unity of Science."49

Of course, one might well wonder what this Bachelardian conception of scientific activity-clearly focused on the experimental sciences-has to do with something like logic or, perhaps more robustly, model theory. But Badiou insists in The Concept of Model that model theory "is an experimental protocol," and so that it is quite necessary to speak of a kind of "practical immanence" between the formal and the material that is put on display in the most rigorous fashion possible in model theory. ${ }^{50}$ Model theory represents a development within (mathematical) logic that clarifies the fully experimental nature of the formal sciences. As Badiou puts it at one point, model theory "is an intramathematical relation between certain refined experimental apparatuses (formal systems) and certain 'cruder' mathematical products [the models], which is to say, products accepted, taken to be demonstrated, without having been submitted to all the exigencies of inscription whose verifying constraints are governed by the apparatus." ${ }^{51}$ It is along these lines Badiou is moving when he calls model theory, rightly understood, as illustrating a materialist epistemology, which is "of a piece with an effective scientific practice." ${ }^{2}$ It is unfortunate, in his view, that the specifically intramathematical relation between a syntax and its semantic models too easily "allows" one to think that it represents instead "the relation between a formal system and its 'natural' exterior"the supposed material world of empirical observation, which formal systems would then somehow "represent." ${ }^{53}$ But any diremption of what is into some kind of ideal (or idealist) formalism and some kind of empirical (or empiricist) materiality cancels the basic materialist commitments of (what Badiou regards as) strict scientific activity.

It is this sort of ideological misconstrual of (scientific) logic that Badiou finds in Frege, although he gives this point sharper definition in the course of his critique. Frege's ideological misconstrual begins, he says, with failure to recognize the stratified nature of the logical machine outlined above. ${ }^{54}$ Every derivable statement, like every non-derivable statement, produced by the logical machine schematized above must pass successively through all three mechanisms-concatenation, formation, and derivation-with the result that any given string of written marks appears (1) as a mere concatenation, (2) as a well-formed or an illformed concatenation, or, finally, (3) as a fully derivable or a fully non-derivable well-formed concatenation. If some string of written marks falls, in the last analysis, within the set of non-derivable statements, it is only rejected, as it were, from the logical system (as a non-derivable statement) after having been first

48 Bachelard, The New Scientific Spirit, 13.

49 Badiou, The Concept of Model, 5. For Carnap's article, see Carnap, “Logical Foundations of the Unity of Science.” Carnap's opening move in this classic essay indeed corresponds the fundamental gesture against which Canguilhem directs his most strenuous attacks: the assumed distinction between the formal and the empirical sciences. See Carnap, "Logical Foundations of the Unity of Science," 42-43; and Canguilhem, Knowledge of Life, 3-24.

50 Badiou, The Concept of Model, 42, 44.

51 Ibid., 42. See, in a similar vein, Badiou's comments in a conversation with Michel Serres: "The theory [of models] cannot appropriate the object. This supposed object is a phenomenon that has certain effects which are ultimately determinable as processes. Hence we have the object, its effects, and the theoretical field, but there is no direct relation. We would thus be constructing, if we can put it this way, something between the theoretical field and the indeterminate or relatively indeterminate object. We would be constructing an intermediate object, a model, controlled by the theoretical field, which would, in its turn, have certain effects and the theoretical control over the model that permits one to obtain a level of effects, a correspondence, an analogy, indirect or detached but which finally permits us to establish a sort of indirect control, a mediate control, of the initial object." Tho and Bianco, Badiou and the Philosophers, 112.

52 Badiou, The Concept of Model, 22. See also ibid., 48-55. Badiou inserts the claim that this represents a specifically "materialist epistemology" directly into the subtitle of The Concept of Model, which is An Introduction to the Materialist Epistemology of Mathematics.

53 Badiou, The Concept of Model, 18.

54 Badiou, "Mark and Lack," 171. 
accepted by the system (as a well-formed statement). Similarly, if some string of written marks is rejected by the mechanism of formation, it is only rejected from the logical system (as an ill-formed expression) after having been first accepted by the system (as a concatenation of written marks). Consequently, Badiou says, "no lack is marked in [the machine] that does not refer to another mark in a subjacent order"-that is, in a preceding mechanism. ${ }^{55}$ This constitutes the system's stratification, and when this is overlooked, ideology threatens to compromise the scientific nature of logic in a particularly subtle form.

This particular ideological conception of logic, according to Badiou, makes a double move. First, as already suggested, it effectively regards the three mechanisms that guarantee the stratification of the logical product as a single machinic operation, treating the logical machine as a kind of black box that, moreover, simply marks the truth of true statements (the derived as true) and the falsity of false statements (the non-derived as false). ${ }^{56}$ Second, Badiou says, the ideological view adds to the three (indistinguished) mechanisms a fourth, $\mathrm{M}_{4}$, which it considers the principal logical mechanism, one that extracts "predicative constant [s]" from all well-formed expressions produced by $\mathrm{M}_{2}$ (that is, from all statements, whether true or false at the end of the operation of $\left.\mathrm{M}_{3}\right) .{ }^{57}$ Taking the true and the false as primitive terms, terms whose applicability serves solely to guarantee the referential meaningfulness (and therefore the scientific viability) of statements, the ideological conception of logic presupposes a certain conception of truth at the outset of all logical work. All logical work, on this ideological view, therefore begins with the task of extracting predicative constants from meaningful statements, meaningfulness being guaranteed in advance by any statement's bearing a truth-value.

It must be underscored that Badiou's descriptions, here, of Frege's conception of logic are unquestionably accurate (even if it remains a question as to whether ideology is really in play). Early on, Frege distinguished his conception of logic from that of his predecessors:

In Aristotle, . . the logically primitive activity is the formation of concepts by abstraction, and judgment and inference enter in through an immediate or indirect comparison of concepts via their extensions. ... I start out from judgments and their contents, and not from concepts. ... Instead of putting a judgment together out of an individual as subject and an already previously formed concept as predicate, we do the opposite and arrive at a concept by splitting up the content of possible judgment. ${ }^{58}$

Here, from very early in his development, Frege himself emphasizes the importance in his conception of logic of what Badiou calls $\mathrm{M}_{4}$, the supplementary mechanism that makes the production (and subsequent manipulation) of predicative constants-that is, Fregean concepts or functions-beginning from judgments secured by their possession of a truth-value the key distinguishing feature of his revolution in logic. This is further and perhaps better illustrated by Frege's somewhat later work on The Foundations of Arithmetic. According to Frege, the first step necessary to understanding the notion of number is to see how numberwords function in sentences with truth-values. Once concepts have been abstracted from true-or-false statements in which a number appears, it is possible to see number as what is attached to such conceptsthat is, it is possible to see that "the content of a statement of number is an assertion about a concept." 59

55 Ibid.

56 It should be noted that, although Ernest Nagel and James Newman perpetuate the idea that Gödel's proof demonstrates that "there is an endless number of true arithmetical statements which cannot be formally deduced from any given set of axioms by a closed set of rules of inference," Francesco Berto among analytic philosophers recognizes with Badiou that "when truth enters the scene” of Gödel's proof, "philosophical argy-bargy begins, and this is properly postponed" until more strictly philosophical-what Badiou would call “ideological”-discourse resumes. Nagel and Newman, Gödels Proof, 98; Berto, There’s Something about Gödel, 125.

57 Badiou, "Mark and Lack," 170.

58 Frege, "Boole's Logical Calculus and the Concept-Script,", 15-17. Frege held to this view of logic until the end of his life, as is clear from Gottlob Frege, "Notes for Ludwig Darmstaedter," 253: "What is distinctive about my conception of logic is that I begin by giving pride of place to the content of the word 'true,' and then immediately go on to introduce a thought as that to which the question 'Is it true?' is in principle applicable. So I do not begin with concepts and put them together to form a thought or judgment; I come by the parts of a thought by analyzing the thought." See also the several components of Frege's very-late "Logical Investigations."

59 See Frege, The Foundations of Arithmetic, 67. 
And from there, it is a relatively simple affair to define numbers as so many self-identical extensions of concepts of the form "concepts equinumerous to such-and-such a determinate concept." ${ }^{60}$ The key point, for the moment, is that Badiou in no way misrepresents Frege's conception of logic at the descriptive level.

If this much is clear, though, it must next be asked why Badiou regards the collapse of $M_{1}, M_{2}$, and $M_{3}$ into a single black box, as well as the addition of $\mathrm{M}_{4}$ to the logical machine, as ideologically problematic. This actually concerns the definition of number just mentioned. Badiou does not attack Frege's general account of number, instead focusing just on Frege's account of one number in particular, the number that secures the whole number series: zero ${ }^{61}$ This draws Badiou's attention because, in the Fregean program, zero must be defined in terms of an empty concept. Frege explicitly chooses to use "the concept 'not identical with itself" (zero is the extension of the concept "concepts equinumerous to the concept 'not identical with itself"'), and this for very specific motives: "I could have used for the definition of nought any other concept under which no object falls. But I have made a point of choosing one which can be proved to be such on purely logical grounds; and for this purpose 'not identical with itself' is the most convenient that offers, taking for the definition of 'identical' the one from Leibniz." ${ }^{62}$ Frege explicitly aims to avoid any worry that he appeals to extra-logical resources to ground the truths of arithmetic. Leibniz's definition of "identical" has already been cited in connection with Jacques-Alain Miller's critique, to which Badiou's essay serves as response, but it is worth quoting in full again, if only to underscore anew that a certain conception of truth is assumed in it, as much by Frege as by Leibniz: "Things are the same as each other, of which one can be substituted for the other without loss of truth." 63

Like Miller, Badiou worries about what role truth plays in Frege's thought at this point. But where Miller claims that Frege's Leibnizian (or even Aristotelian) commitment to the law of non-contradiction distracts him from the deeper logic of Lacanian psychoanalysis, ${ }^{64}$ Badiou worries-like Frege-that the extra-logical creeps into the definition of zero. And Badiou's understanding of what compromises pure logic is stricter than Frege's. Essentially, Badiou understands Frege's Leibnizian definition of identity to operate within $\mathrm{M}_{4}$, hence outside the strict, stratified logical machine. Because Leibniz takes identity to be basic, Frege accepts it as purely logical, but Badiou insists that Leibnizian identity operates within a regime of language where meaning is guaranteed by truth-conditions-that is, precisely, $M_{4}$. For Frege, in Badiou's terms, "zero marks within the non-rejected division of $\mathrm{M}_{4}$ what has been [rightly] rejected in $\mathrm{M}_{3}$ "-namely, the statement $\sim \mathrm{I}(x, x)$ (" $x$ is not identical to $x$ "). ${ }^{65}$ But according to Badiou, "such descriptions are foreign to logical theory. The zero is simply an inscription accepted by $\mathrm{M}_{2}$," where $\sim \mathrm{I}(x, x)$ is considered well-formed and the matter of derivability is not yet raised. ${ }^{66}$ For Badiou, then, "the zero marks . . a a [well-formed] relation lacking in [the set of derived statements in] $\mathrm{M}_{3}$, the relation $\sim \mathrm{I}(x, x)$," rather than marking "the lack of a term satisfying a relation" in $\mathrm{M}_{4}$ (as in Frege). ${ }^{67}$ Frege's recourse to Leibniz thus entraps him, according to Badiou, within a view of logic that relies on the supposedly material empirical world, and especially on the existence or non-existence of certain terms or objects there. ${ }^{68}$

What signals this most straightforwardly is, in the end, the use of the word "truth" in the Leibnizian definition of "identical" used by Frege. What guarantees the meaningfulness of Frege's definition for zero, despite the fact that no term or object satisfies the function or concept it deploys ("not identical with

60 See Ibid., 67-81.

61 It is only in a footnote that Badiou offers any general criticism of Frege's account of number. Even there, though, he seems to appreciate the "theoretical attempt to construct the finite cardinals" undertaken by Frege, focusing the accusation of ideology on the definition of zero. Badiou, "Mark and Lack," 170.

62 Frege, The Foundations of Arithmetic, 88, emphasis added.

63 Ibid., 76.

64 For a most helpful recent articulation of Lacan's esoteric debate with Aristotle, see especially Cassin, "Ab-sense, or Lacan from A to D."

65 Badiou, "Mark and Lack," 170.

66 Ibid.

67 Ibid., 170.

68 Badiou elsewhere in his work in the late 1960s cites Bachelard's claim that "the true principle of identity is that of the identity of scientific instruments," which would include model theory. Badiou, The Concept of Model, 26. Badiou draws this notion from Bachelard, L'activité rationaliste de la physique contemporaine, 77. 
itself"), ${ }^{69}$ is the network of truth-conditions that operate in the real-world, material-empirical context of $\mathrm{M}_{4}{ }^{70}$ Badiou's way of describing this is to speak of "the lexicon of subsumption," a sort of discourse where logical signs are taken to pick out (or not) ${ }^{71}$ a determinate set of (real) objects from within the materialempirical realm that is distinct from the purely formal realm of logic. ${ }^{72}$ The notion of subsumption Badiou declares to be "enclosed in the (specular) referential relation, like the related notion of denotation," such that it "masks the strictly functional essence of the mappings at work inside logical mechanism." ${ }^{73}$ Where semantics is instead regarded as an intramathematical operation, a "syntax of the difference between syntaxes," it follows that "the Leibnizian requirement of self-identity, necessary in order to preserve truth, is intra-logical (theoretical) only insofar as it pertains to the identity of marks." ${ }^{\prime 4}$ That is, to avoid the muddled ideological move of assuming an analogy between the syntax-semantics couple and the ideareality couple, one must to take the principle of identity to hold only for the marks concatenated by $\mathrm{M}_{1}$ in the logical machine (and for the several mechanisms themselves). Where it is assumed that the principle hold also-and especially primarily-for empirically observable objects, the ideological conception of semantics asserts itself.

\section{Consequence}

Such is Badiou's criticism of Frege. Despite the latter's efforts to keep extra-logical factors from playing a role in his strictly logical derivations of arithmetic, the extra-logical creeps in, and it does so because Frege takes his logic to be in some sense the map of "the True." This means, in the end, that what Badiou regards as Frege's ultimately ideological conception of mathematical logic is rooted in a commitment worked out substantially in his most famous paper-one that ostensibly has little to do with mathematical logic: "On Sense and Meaning." There Frege argues not only "that the meaning of a sentence may always be sought, whenever the meaning of its components is involved; and that this is the case when and only when we are inquiring after the truth-value"; he argues also that "every assertoric sentence concerned with what its words mean is therefore to be regarded as a proper name, and its meaning, if it has one, is either the True or the False." ${ }^{75}$ Famously, for Frege, the referent of every meaningful (assertoric) sentence is either "the True" or "the False." Although it remains obscure exactly what Frege means when he speaks of "the True" and, especially, "the False," it is clear that it is the referential relationship between sentences and these "objects" that secures linguistic meaning. ${ }^{76}$ This conception of things eventually led Frege to defend the position that truth is radically undefinable-that every "attempt to define truth" ultimately "breaks down" because "in a definition certain characteristics would have to be specified," but "in application to any particular case the question would always arise whether it were true that the characteristics were present." The necessarily circular form every definition of truth must take yields the conclusion that "the content of the word 'true' is sui generis and indefinable." ${ }^{77}$ But it is precisely this primitive and indefinable conception of truth that, for

69 For Frege's classic argument that concepts are operationally equivalent to (mathematical) functions, see Frege, "Function and Concept."

70 See, classically, Davidson, “Truth and Meaning." For a parallel argument made in the name of continental philosophy, but in conversation with analytic philosophy, see Wrathall, "The Conditions of Truth in Heidegger and Davidson."

71 Badiou describes Frege's appeal to the empirical, where nothing satisfies the function in question, as "an evanescence, a shimmering oscillation.” Badiou, "Mark and Lack,” 166.

72 Badiou, "Mark and Lack,” 165.

73 Ibid.

74 Ibid., 166, emphasis added. Badiou's inspiration here is, again, Bachelard. Badiou puts the point also as follows: "It is the technical invariance of traces and instruments that subtracts all ambiguity from the substitution of terms." Ibid.

75 Frege, "On Sense and Meaning," 163. For extended commentary, see Dummett, Frege, 401-29.

76 Joan Weiner warns, in connection with the way that sentences refer to "the True" and "the False," that "Frege is introducing a new, logical notion of objecthood-a notion that has only limited connection to our everyday notion." Weiner, Frege, 98. For the closest Frege comes to providing a technical definition of "object," see Frege, "On Concept and Object," 187: "An object is something that can never be the total meaning of a predicate, but can be what a subject means."

77 Frege, “Logical Investigations,” 353. 
Badiou, lies at the root of the problem. Primitive-and therefore always presupposed-truth assumes, from Badiou's perspective, something extra-logical, compromising the strict immanence of the syntactic to the semantic, or of the semantic to the syntactic.

Thus, despite Frege's brilliant and famous argument against every conception of truth in terms of correspondence, ${ }^{78}$ Badiou sees him reproducing the basic philosophical commitments of every correspondence theory of truth. Frege essentially takes the "relation between syntactic deducibility ... and semantic validity" to be equivalent to the relation (however loosely defined) between the idea of a thing (in the form, specifically, of linguistic sentences) and the empirical reality of a thing (in the form, mysteriously, of the referent the True). ${ }^{79}$ Even if it is possible to argue that the Fregean notions of "the True" and "the False" cannot be equated in any obvious way with, say, the totality of empirical reality-especially in a naïve way-Badiou can point to Frege's use of Leibniz's definition of identity as symptomatic, indicative that "truth" operates in the realm of empirical objects that do or do not satisfy certain functions.

All this might be approached from a rather different angle. In a 2007 interview about The Concept of Model, Badiou explains his lingering interest in his early work in the following way: "the model [in the strict mathematical or scientific sense] is that which allows us to think through [Platonic] participation." ${ }^{80}$ What Badiou sees as Frege's misstep with respect to logic and model theory amounts in the end to a failure to engage directly and forcefully with a basic philosophical question first posed by Plato. And it must be stated right away that important analytic interpreters of Frege have themselves considered Frege's relationship to Plato on this very question, most crucially Donald Davidson in Truth and Predication. ${ }^{81}$ Indeed, Frege himself-albeit without directly citing Plato (or Aristotle on the same subject)-very early presented his logical and philosophical reflections as providing a full solution to the so-called "Third Man" argument from Plato's Parmenides. ${ }^{82}$ Badiou effectively insists that model theory provides the first fully rigorous, or the first fully scientific, means for thinking all the way through the infamous relationship ("participation") between Platonic forms (here regarded from a perspective uninterested in naïve formulations of Plato's supposed metaphysical commitments) and things apparent in what Plato (naively) regarded as the sensible realm. Frege, from Badiou's perspective, ignores these scientific means in his insistence on the primitive or immediate saturation of predicates (Platonic forms) by objects (things in the sensible realm). And, of course, this immediacy is guaranteed, for Frege, by the truth-secured meaningfulness of sentences, from which predicates and objects are only to be extracted "by decomposition." ${ }^{83}$ In a word, then, Frege does not so much scientifically solve as ideologically ignore the Platonic problem of predication. And, to be sure, because of Plato's apparent metaphysical commitments, this way around Plato's basic problem can take on the appearance-in Rudolf Carnap, for instance-of a strictly scientific commitment in a reinvention of philosophy. This is not surprising, since, as Badiou himself notes, logical positivism-he has reference especially to Carnap-has always been involved in "a dialectical complicity" with science, and with mathematical logic in particular. ${ }^{84}$

What, then, would a strictly scientific account of truth look like, for Badiou? The answer, it seems to me, is simple. It would look like the work undertaken by Alfred Tarski in his famous paper, "The Concept of Truth in Formalized Languages." ${ }^{85}$ Despite Tarski's overt commitment (but later clarified) to "grasping the intentions which are contained in the so-called classical conception of truth ('true-corresponding

78 See Frege, “Logical Investigations,” 352-53. Crucially, from a Badiouian perspective, Frege presents this argument without directly clarifying his earlier arguments that "the True" is the referent of (meaningful) true sentences. The argument concerns solely the predicate "true" and not what it means to say that "the True" is an object (logical or otherwise) or what is at issue in the referential relationship between true sentences and "the True."

79 Badiou, The Concept of Model, 31.

80 Ibid., 92.

81 See, of course, Davidson, Truth and Predication, 130-40.

82 See Frege, Philosophical and Mathematical Correspondence, 100-101. For Plato's argument, see, of course, Plato, Parmenides, 132a-b.

83 Frege, Philosophical and Mathematical Correspondence, 101.

84 Badiou, The Concept of Model, 19.

85 See Tarski, "The Concept of Truth in Formalized Languages.” 
with reality')," ${ }^{86}$ his actual approach to defining truth bars his account from coinciding with the kind of ideological recapture Badiou criticizes. ${ }^{87}$ How does Tarski avoid the ideological? By refusing to countenance the project of defining truth in general, opting instead to construct particular definitions of truth within the intramathematical relationship between particular formal languages and the various models appropriate to them. Further, as Donald Davidson notes, "Tarski provides no entities at all to which sentences correspond or which sentences name, picture, or otherwise represent. No facts appear in the official apparatus, nor do propositions, either as the meanings of sentences or as half-extensional, half-intensional entities in the world as in [Bertrand] Russell's early theory." ${ }^{88}$ Thus, already in the introduction to his celebrated essay, Tarski states that "there will be no question at all here of giving a single general definition of the term ['truth']" because "the extension of the concept to be defined depends in an essential way on the particular language under consideration." ${ }^{89}$ By beginning from a particular syntax and in the course of developing the semantics appropriate to that particular syntax, Tarski constructs the concept of truth just for that particular syntax (essentially defining truth as what holds across all semantic models of a particular syntax or formal language) and never indicates that the models proper to the formal language in question in some obvious or discoverable way provide a map of the world of "empirical reality." Tarski does develop a "general scheme" for constructing the concept of truth for any syntax (of a certain sort), ${ }^{90}$ but he never suggests that this general scheme (later formulated as the famous T-schema or Convention T) amounts to a definition or concept of truth in general..$^{11}$ Instead, there are as many concepts of truth as there are (formalized) languages. ${ }^{92}$ All this amounts to a consistent demand, on Tarski's part, that truth remain always and indelibly defined in what Badiou calls intramathematical terms. Tarski's account of truth remains, in Badiou's terms, fully scientific and epistemologically materialist. (Obviously, it is no accident that Tarski largely ended up inventing the discipline to which Badiou refers so often in his 1960s writings: model theory. $)^{93}$

What Badiou regards as Frege's ideological conception of logic thus contrasts directly with what Badiou regards as Tarski's scientific conception of logic, with each positioning truth differently in outlining the nature of logic. Frege takes truth as an undefined primitive term, operative in the realm of the empirical or the material (as ideologically distinguished from the realm of the formal or the ideal), while Tarski takes truth to be scientifically definable precisely for particular languages in an intramathematical construction that refuses to posit any compromising distinction between the empirical or material and the formal or the ideal. Given the overt commitments of each of these thinkers, on display throughout their respective writings, this seems to be an accurate analysis of their real difference and therefore a helpful typological analysis of options on offer in early analytic philosophy. Of course, one might-even while giving credit to the distinction drawn by Badiou between the two projects - hesitate to use Badiou's (Althusserian) terms, "scientific" and "ideological," given the heavy value judgments that come with them. Indeed, one

86 Tarski, “The Concept of Truth in Formalized Languages,” 153. For later clarification of Tarski’s epistemological commitments, see Tarski, "The Semantic Conception of Truth, and the Foundations of Semantics," 342-45, 359-62.

87 While Frege criticizes the correspondence theory but reproduces its ideological commitments (from Badiou's perspective), Tarski does not (at first) criticize that theory but nonetheless scientifically eliminates its relevance.

88 Davidson, Truth and Predication, 155. Davidson continues: "It is true that Tarski suggests, in his informal defense of the claim that his constructions capture the intuitive concept of truth, that his truth definitions embody the idea that true sentences correspond to the facts. But this is misleading, since in his work on truth there is nothing for sentences to correspond to." Davidson, Truth and Predication, 155-56.

89 Tarski, “The Concept of Truth in Formalized Languages,” 153.

90 Ibid., 155.

91 Ibid., 187-88.

92 Tarski concludes early in his work that "the very possibility of a consistent use of the expression 'true sentence' which is in harmony with the laws of logic and the spirit of everyday language seems to be very questionable, and consequently the same doubt attaches to the possibility of constructing a correct definition of this expression." Tarski, "The Concept of Truth in Formalized Languages," 165. See also Tarski, "The Semantic Conception of Truth," 347: "For other languages-thus, for all natural, 'spoken' languages-the meaning of the problem is more or less vague, and its solution can have only an approximate character.”

93 It should be noted that recent work has suggested that Leopold Löwenheim's importance in the early development of model theory has been overlooked. See Badesa, The Birth of Model Theory. 
might well object that Badiou's value-laden critique is in fact historically unfair, since the development of model theory came only years-decades!-after Frege's most important work. Certainly, Frege never studied mature model theory and then perversely decided to obscure its scientificity by overlaying it with pernicious ideological commitments. Frege was (in this regard) no reactionary. ${ }^{94}$ What, then, should be made of Badiou's apparently anachronistic critique? Could he not just as well criticize any pre-Tarskian conception of truth with as much effect, and perhaps more honestly? Is there not something problematically opportunistic about Badiou's critique of Frege?

Earlier, I used Badiou's debt to Gaston Bachelard to clarify his notion of "the scientific," as well as to clarify in a preliminary way his notion of "the ideological." The latter term deserves fuller clarification at this point, and with reference to the other major French philosopher of science to whom Badiou claimed to owe much: Georges Canguilhem. Badiou does not present himself as a historian of mathematics, but Canguilhem's claim that "the historian of mathematics must take his provision definition of what mathematics is from contemporary mathematics" suggests something of the alignment between Badiou's thinking and that of Canguilhem. ${ }^{95}$ Thus it seems significant that Canguilhem explicitly distinguishes "scientific ideology" from "political class ideology" because the former, unlike the latter, is not a form of reaction (it is "not false consciousness"); instead, "a scientific ideology comes to an end when the place that it occupied in the encyclopedia of knowledge is taken over by a discipline that operationally demonstrates the validity of its own claim to scientific status, its own 'norms of scientificity.' At that point, a certain form of a nonscience is excluded from the domain of science." ${ }^{" 66}$ For Canguilhem, in other words, scientific ideology is what genuine science displaces, and science accomplishes this displacement in part through the establishment of certain "norms of scientificity," that is, by establishing something like what Thomas Kuhn called a "paradigm": a collection of "concepts, discourses, speculations, and experiments" that work together as a total network. ${ }^{97}$ Hence, the state of a particular science at any given time is "neither the logical consequence nor the historical culmination of any prior state of a developed science"-Canguilhem explicitly rejects the notion of the scientific "precursor." ${ }^{98}$ Science makes all of its supposed precursors into scientific ideologies at the moment of its rise.

Strictly speaking, then, the notion of the ideological that Badiou arguably adopts from Canguilhem is one in which a particular scientific ideology definitively comes before the science that displaces it. ${ }^{99}$ In undertaking an Althusserian philosophical critique of early analytic philosophy, therefore, Badiou means in his late-1960s work to show how the emergence of a strictly scientific conception of logic and of truth (in fully only in the 1930s) provided a set of scientific norms that, from an epistemological point of view, allows for the clear diagnosis of the scientific ideologies displaced by such developments (those developed in the 1880s). Badiou's aim is therefore less to render some kind of anachronistic judgment on Frege's work than to draw a clear line of demarcation between his not-yet-scientific work on logic and the more strictly scientific work undertaken in the 1930s by Tarski and others. He means really just to note that the norms of scientificity introduced by later work retroactively render earlier work ideological.

94 Sadly, Frege embraced unseemly political views late in his life, outlined in writings that were only published posthumously. See Gabriel and Keinzler, "Diary.”

95 Canguilhem, A Vital Rationalist, 31.

96 Ibid., 35.

97 Ibid., 50. See also ibid., 30: "Without concepts, there is no science. The history of science is interested in, say, the history of instruments or of academies only insofar as they are related, in both their uses and their intentions, to theories.” Regarding Kuhn, note that Canguilhem directly critiques the latter's use of his concepts that are otherwise in so many ways similar to Canguilhem's own: Canguilhem, A Vital Rationalist, 45-46.

98 Ibid., 29, 49-52. See ibid., 50: "A precursor, therefore, is a thinker whom the historian believes can be extracted from his cultural milieu and inserted into others.... Such adaptability, of course, is obtained at the cost of neglecting the "historicity' of the object under study."

99 When Canguilhem says that "the existence of scientific ideologies implies that parallel and prior existence of scientific discourses," he means not that scientific ideologies are reactions to real scientific developments, but that scientific ideologies are once-scientific theories that end up displaced rather than, say, religious conceptions of the world made irrelevant by the scientific worldview. Canguilhem, A Vital Rationalist, 36. 
Yet, the sharp edge of Badiou's critique should not be blunted too quickly. The point of drawing a philosophical line of demarcation between the scientific and the ideological is not just to make a historical point. It must be said again that Badiou is not a historian of mathematics. ${ }^{100}$ He writes and speaks as a philosopher, and the Althusserian vision that inspired his 1960s work understood philosophy to be a polemical battle to be measured by (political) "correctness" rather than (ideological) "truth."101 For this reason, it is crucial that The Concept of Model criticizes the alleged ideological commitments not of the pre-scientific-and-therefore-ideological Frege, but rather the alleged ideological commitments of Frege's own post-scientific student, one who would write a great deal about scientific semantics: Rudolf Carnap. ${ }^{102}$ Badiou never makes the argument explicitly, but one surmises that he means to suggest that Carnap resumes the specifically Fregean conception of logic even as he attempts to take over the TarskianGödelian scientific conception of semantics. ${ }^{103}$ Certainly, he accuses both Frege and Carnap of exhibiting the same ideological commitments, despite Frege's pre-scientific position in the history of mathematical logic and Carnap's post-scientific position in the same history. Thus the point of Badiou's demarcation of the boundary between genuinely materialist science and scientific ideology would apparently be to reveal the ways in which certain thinkers-exemplified by Carnap-compromise scientific materialism in their philosophical appropriations of the sciences, due largely to their continuity with pre-scientific ideological conceptions (like Frege's). Carnap's Fregean commitments, apparent throughout his writings, suggest that, despite the fact that he often treats semantics in a more strictly scientific manner, his specifically philosophical uses of the science of semantics hark back to the ideological compromises made by Frege's pre-scientific conception of logic and truth. ${ }^{104}$

That Badiou's critique of Carnap suggests something like a more general critique of the Fregean inheritance within analytic philosophy-as opposed to the Fregean inheritance, to whatever extent it exists, within strictly scientific mathematical logic-seems clear from a move Badiou makes at just one point in The Concept of Model. Although he most generally takes aim at Carnap throughout that book, in one crucial passage he argues briefly that Carnap and his student, W. V. O. Quine, share a "common motor," specifically the (implicitly Fregean) ideological distinction "between 'fact' and logical form."105 This requires some argument, since, as Badiou himself notes, Carnap opposes himself to Quine and his claim that "the empirical is a dimension of the formal, or vice versa."106 I will not here defend Badiou's extension of the critique from Carnap to Quine (although these two thinkers are arguably closer than is often asserted, as Paul Livingston argues), because I prefer to focus on Donald Davidson-whom Badiou

100 Somewhat peculiarly, Badiou seems to close The Concept of Model with an insistence that he is in fact doing history: "The problem is not, and cannot be, that o the representational relations between the model and the concrete, or between the formal and the models. The problem is that of the history of formalization. 'Model' designates the network traversed by the retroactions and anticipations that weave this history: whether it be designated, in anticipation, as break, or in retrospect, as remaking." Badiou, The Concept of Model, 54-55, emphasis in original.

101 See Althusser, "Philosophy and the Spontaneous Philosophy of the Scientists", 74-83, where Althusser articulates the idea that philosophy is worked out on a "battlefield," with each philosopher staking out a "position." Badiou continues into the present defending the idea that the philosopher always assumes the position of the master; see Badiou, Conditions, 26-32.

102 Carnap's notes on Frege's lectures are available in print. See Reck and Awodey, Frege's Lectures on Logic. Frege, of course, appears throughout Carnap's writings.

103 On Tarski's and Carnap's relationship, see Coffa, The Semantic Tradition from Kant to Carnap, 272-374.

104 For one of Carnap's more obviously scientific treatments of precisely these kinds of projects, see Rudolf Carnap, Introduction to Semantics (Cambridge: Harvard University Press, 1948). It is difficult to see Fregean ideological commitments on display in such a work. By contrast, the kind of work undertaken in Carnap, Meaning and Necessity, is more obviously of the sort that Badiou implicitly criticizes.

105 Badiou, The Concept of Model, 7. Badiou points specifically to Quine's "On What There Is.” See Quine, "On What There Is.” 106 Badiou, The Concept of Model, 6. It deserves notice also that, in a footnote in "Mark and Lack," Badiou uses Quine's critique of Bertrand Russell's axiom of reducibility in order to criticize Frege's de-stratification of the logical machine. See Badiou, "Mark and Lack," 171. It might be noted that the English text wrongly speaks of "Wilfred Quine," a mistake of the translators and/or editors of the English text, since Badiou's original cites "W. V. O. Quine, «On the axiom of reducibility» in Mind, 45, 498-500." Badiou, "Marque et Manque," 161. It seems worth noting this partially in order to underscore the general unfamiliarity with analytic thought on the part of those actively working on Badiou's philosophy. 
does not mention, but whose direct and explicit interest in Tarski makes him a clearer target. ${ }^{107}$ And frankly, the very existence of Badiou's argument for an extension of the critique is enough to make clear that he assumes the possibility of detecting in much of analytic thought "the generality of a given ideology"-one that implicitly depends on Frege and persists in key contributions after the watershed contributions of Quine just before and after World War II. ${ }^{108}$ At any rate, given that Quine is consistently taken to provide the basic starting point for the general revitalization of metaphysics in the analytic philosophical tradition, ${ }^{109}$ and more fundamentally to mark the transition of analytic philosophy into its post-empiricist maturity, ${ }^{110}$ it seems clear that Badiou sees the complicity between Carnap and Quine as having larger implicationsimplications that potentially stretch in relevance beyond the 1960 s.

By way of conclusion to this exposition of Badiou's critique of Frege, then, I wish to outline, however briefly, the sketch of a preliminary argument that Badiou's critique might have implications for analytic thought as it continues to be practiced, but less in the direct wake of Quine than in the wake of Davidson's repurposing of Quine's work. It remains a question whether Quine can be assimilated so smoothly to Carnap because of his Fregean commitments to a certain allegedly ideological conception of how the distinction between syntax and semantics maps onto "reality." Davidson, however, seems to me more obviously to use the Fregean conception Badiou criticizes to ground the project of analytic metaphysics, and he does it by explicitly and deliberately shifting away from what Badiou regards as the scientific aspect of Tarskian model theory.

At first, it appears that Davidson overtly rejects the basic ideological view he criticizes in Frege and Carnap. In his famous critique of Thomas Kuhn, Davidson dubs "the third dogma" of empiricism any "dualism of scheme and content, of organizing system and something waiting to be organized." Davidson in fact goes so far as to say that such a dualism "cannot be made intelligible and defensible." 111 Even leaving aside Kuhn's (in my view, convincing) response to Davidson's critique, ${ }^{112}$ one finds here a relatively clear indication that Davidson explicitly rejects the basic distinction Badiou attributes to Carnap and Quine. In fact, Davidson partially rejects the distinction by, like Badiou, attributing it to Quine, as the one dogma of empiricism he did not shake off ("the same, or similar, thoughts are expressed by Quine in many passages"). ${ }^{113}$ All this suggests that Davidson explicitly and intentionally escapes whatever critique Badiou might be making of analytic philosophy up to and including Quine. Further, Davidson-also rather like Badiou-makes an appeal to Tarski's scientific work on the notion of truth in order to escape the ideological (or dogmatic) move of positing a dualism of scheme and content. "Nothing, however, no thing, makes sentences and theories true," he explains, neither "experience" nor "the world." "That experience takes a certain course, ... that the universe is finite, these facts, if we like to talk that way, make sentences and theories true. But this point is put better without mention of facts. The sentence 'My skin is warm' is true if and only if my skin is warm. Here there is no reference to a fact, a world, an experience, or a piece of evidence." ${ }^{114}$ Here Davidson has direct and unmistakable reference to Tarski's famous Convention T: $p$ is true if and only if $\mathrm{p}$. For Davidson as much as for Badiou, the only way to eliminate the third dogma of logical empiricism-or to draw a line of demarcation between the ideological and the scientific-is to recognize the crucial philosophical and/or scientific progress made by Tarski as he laid the foundations of model theory.

107 See Livingston, Philosophy and the Vision of Language, 97-122.

108 Badiou, The Concept of Model, 6.

109 Thus Berto and Plebani, Ontology and Metaontology, 34 - 51, can speak of Quine’s basic position regarding “what there is” as "the standard view."

110 See, for instance, Soames, “The Place of Willard Van Orman Quine in Analytic Philosophy.”

111 Davidson, “On the Very Idea of a Conceptual Scheme,” 189.

112 See Kuhn, "Commensurability, Comparability, Communicability."

113 Davidson, "On the Very Idea of a Conceptual Scheme," 191. See, of course, Quine, "Two Dogmas of Empiricism.”

114 Davidson, “On the Very Idea of a Conceptual Scheme,” 194. 
Why, then, should one not conclude that Badiou and Davidson are largely aligned? ${ }^{115}$ The answer is that Davidson's Tarski is, famously, an inverted Tarski ${ }^{116}$-a Tarski restored to a Fregean philosophical position in a crucial regard. What interests Davidson is emphatically not the scientific progress made by Tarski's foundational work in model theory, the way that Tarski pushes mathematical logic further in the direction of a strict materialism. Davidson himself explains that Tarski's interest in providing specific definitions of truth for particular formal languages (bound by a strict commitment to consistency) runs against his own interests: "I have forsworn the step which yields explicit definitions [for particular languages], and am therefore regarding Tarski's constructions as axiomatizations of the intuitive, and general, concept of truth," precisely the thing that Tarski avoids and therefore-according to Badiou-achieves strict scientificity. Davidson concedes that his own project therefore "does not have the proven innocence [that is, scientific purity] of the defined concept, and thus would not, as I said, have been welcome to Tarski. This is the cost of being in a position to apply the method to actual languages." ${ }^{117}$ And what inspires the non-Tarskian aspects of Davidson's philosophical orientation here? He is quite explicit, throughout his work, that it is Frege who drives this aspect of his project. Already in "Truth and Meaning," first published the very year that Badiou originally wrote "Mark and Lack," Davidson makes his basic Fregean orientation clear-not only in that he sees meaning as dependent on linguistic context (the famous "context principle"), but also in that he sees truth as an undefinable primitive term that guarantees the meaningfulness of all communication. ${ }^{118}$ Still more forcefully, at the end of his life, Davidson made perfectly clear that it was less Tarski than Frege whom he saw as finding the way around every dualism of content and scheme. If such a dualism is only overcome where meaning is guaranteed by a primitive translatability between truth-conditions and true statements, ${ }^{119}$ then it is Frege who ultimately stands behind Davidson's critique of the third dogma of empiricism. Thus in Truth and Predication, Davidson says this: "Of all the efforts to account for the role of predicates that we have reviewed, Frege's is the only one that, by its treatment of predicates, clearly makes sentences semantic units. Of the attempts we have considered, Frege alone has assigned a semantic role to predicates which promises to explain how sentences are connected to truth values." ${ }^{120}$ All that Tarski, in Davidson's view, adds to Frege is a kind of technical fine-tuning: "Tarski's methods allow us to specify the roles of the smallest meaningful parts in an infinity of sentences in a way that allows us to prove, in the case of any sentence, what its truth conditions are."121

Davidson strips from Tarski's project precisely what Badiou regards as its scientificity. He creates a kind of Fregean Tarski, or rather, he extracts from Tarski's scientific work a schema that he then uses to deepen and to clarify Frege's basic conception. From Badiou's perspective, despite his polemic against the third dogma of empiricism, Davidson falls into the same ideological trap as Frege and Carnap. In essence, Badiou's implied critique of the Davidsonian project would be equivalent to his explicit critique of the Fregean project. Although Davidson, like Frege, usefully critiques naïve conceptions of truth along the lines of correspondence, ${ }^{122}$ and although he, like Frege, rightly sees his project as directly addressing the Platonic problem of participation, ${ }^{123}$ he also, like Frege, insists on primitive or immediate saturation of predicates by objects and therefore does not so much scientifically solve as ideologically ignore the problem. If Badiou's critique of Frege on this point holds at all, it holds as well of Davidson. This is as much as to say that what Badiou says of Quine in The Concept of Model-noted above-could easily have been squarely aimed at Davidson as well had Badiou been aware of his then-still-incipient project. The apparent "opposition

115 Samuel Wheeler has argued in numerous places that Davidson should be seen as closely aligned, philosophically, with Jacques Derrida. See, for example, Wheeler, "Davidson, Derrida, and Difference."

116 This is clearest in Donald Davidson, "Radical Interpretation," in Inquiries into Truth and Interpretation, 134.

117 Davidson, Truth and Predication, 160.

118 See Davidson, "Truth and Meaning," 29: "There may in the nature of the case always be something we grasp in understanding the language of another (the concept of truth) that we cannot communicate to him."

119 See Davidson, “On the Very Idea of a Conceptual Scheme,” 194-95.

120 Davidson, Truth and Predication, 133-34.

121 Ibid., 155. See the fuller elaboration of this "essential" but entirely technical "innovation" ibid, 159.

122 See the nuanced discussion in Davidson, "True to the Facts."

123 This is the point of Davidson's Truth and Predication. 
between Carnap and Quine,” Badiou argues, "is internal to the same problematic. Quine, in effect, defines the particularity of his enterprise (the originality of his project) by justifying the negation of a distinction that Carnap, for his part, aims to reduce.... All that matters to Quine is the justification of the claim that there is no need to reduce what can conveniently be denied"-namely, the gap between the formal and the empirical. ${ }^{124}$ Badiou would likely say the same of Davidson. The latter provides no scientific account of the formal and the material, no intramathematical explanation of their strict immanence; he simply denies their extrication and secures the justifiability of this denial by insisting on the primitive indefinability of truth. ${ }^{125}$

Badiou's critique of pre-1960s analytic philosophy therefore seems relevant to major figures working at the foundations of the rebirth of analytic metaphysics. Not only does he explicitly critique Quine, whose basic approach remains central to contemporary analytic metaphysics, he also provides the outline of an argument that can be directed in far more specific and forceful ways at the foundations of Davidson's metaphysical project. Davidson famously makes his repurposing of Tarski's work on semantics the basis for a revitalization of metaphysics. "In sharing a language, in whatever sense this is required for communication, we share a picture of the world that must, in its large features, be true," Davidson claims. "It follows that in making manifest the large features of our language, we make manifest the large features of reality. One way of pursuing metaphysics is therefore to study the general structure of our language"-for which the (inverted) Tarskian schema provides a map. ${ }^{126}$ To the extent that a certain "pragmatism" (as Quine called it) about the communicability of the world allows for the construction of a reliable metaphysics, ${ }^{127}$ and to the extent that this pragmatism ultimately relies on a Fregean conception of the relationship between truth and meaning, the Badiou of the late 1960s would presumably argue that ongoing work in the analytic tradition-whether Quinean or Davidsonian in orientation-ultimately rests on an unexamined ideological philosophical of science. Although this argument has largely failed to draw attention, it deserves to be a part of the conversation surrounding what it means to undertake metaphysics beginning from questions of logical form. Does Badiou's critique-drawing in turn on too-often overlooked philosophers of science like Gaston Bachelard and Georges Canguilhem-help to shed light on the relationship between analytic metaphysics and the hard sciences? Are there inherent problems in Badiou's framing that would make the critique less than salient or relevant? These are questions that remain to be debated seriously.

\section{References}

Althusser, Louis. For Marx. Trans. Ben Brewster. New York: Verso, 2005.

Althusser, Louis. The Future Lasts Forever: A Memoir. Ed. Olivier Corpet and Yann Moulier Boutang. Trans. Richard Veasey. New York: The New Press, 1993.

Althusser, Louis. On the Reproduction of Capitalism: Ideology and Ideological State Apparatuses. Trans. G. M. Goshgarian. New York: Verso, 2014.

Althusser, Louis. "Philosophy and the Spontaneous Philosophy of the Scientists" and Other Essays. Ed. Gregory Elliott. Trans. Ben Brewster et al. New York: Verso, 1990.

Bachelard, Gaston. L'activité rationaliste de la physique contemporaine. Paris: Presses universitaires de France, 1951.

Bachelard, Gaston. Les intuitions atomostiques: essai de classification. Paris: J. Vrin, 2016.

Bachelard, Gaston. The New Scientific Spirit. Trans. Arthur Goldhammer. Boston: Beacon Press, 1984.

Badesa, Calixto. The Birth of Model Theory: Löwenheim's Theorem in the Frame of the Theory of Relatives. Princeton: Princeton University Press, 2004.

Badiou, Alain. Being and Event. Trans. Oliver Feltham. New York: Continuum, 2006.

124 Badiou, The Concept of Model, 6-7, emphases in original.

125 It seems to me that Quine's and Davidson's shared position regarding radical translation-and, of course, regarding the metaphysical relevance of radical translation-that would especially make Badiou's critique of Quine equivalent to a theoretical critique on his part of Davidson's enterprise. See, of course, Quine, Word and Object, 26-79; and Davidson, "Radical Interpretation."

126 Davidson, "The Method of Truth in Metaphysics," 199.

127 See Quine, “Two Dogmas of Empiricism,” 31. 
Badiou, Alain. The Concept of Model: An Introduction to the Materialist Epistemology of Mathematics. Ed. and trans. Zachary Luke Fraser and Tzuchien Tho. Melbourne: re.press, 2007.

Badiou, Alain. Conditions. Trans. Steven Corcoran. New York: Continuum, 2008.

Badiou, Alain. “Formulas of L'Étourdit.” In Alain Badiou and Barbara Cassin, There's No Such Thing as a Sexual Relationship: Two Lessons on Lacan, trans. Susan Spitzer and Kenneith Reinhard (New York: Columbia University Press, 2017), 45-62.

Badiou, Alain. Infinite Thought: Truth and the Return of Philosophy. Trans. and ed. Oliver Feltham and Justin Clemens. New York: Continuum, 2004.

Badiou, Alain. Logics of Worlds: Being and Event II. Trans. Alberto Toscano. New York: Continuum, 2009.

Badiou, Alain. "Mark and Lack." Trans. Zachary Luke Fraser and Ray Brassier. In Concept and Form: Key Texts from the "Cahiers pour l'Analyse", 2 vols., ed. Peter Hallward and Knox Peden (New York: Verso, 2012), 1:159-85.

Badiou, Alain. “Marque et Manque: à propos du Zéro.” Cahiers pour l'Analyse 10.8 (Winter 1969): 150-73.

Badiou, Alain. Metapolitics. Trans. Jason Barker. New York: Verso, 2005.

Badiou, Alain. Number and Numbers. Trans. Robin Mackay. Malden, MA: Polity, 2008.

Badiou, Alain. Pocket Pantheon: Figures of Postwar Philosophy. Trans. David Macey. New York: Verso, 2009.

Badiou, Alain. "The (Re)commencement of Dialectical Materialism." In The Adventure of French Philosophy, ed. and trans. Bruno Bosteels (New York: Verso, 2012), 133-70.

Badiou, Alain. The Subject of Change: Lessons from the European Graduate School. Ed. Duane Rousselle. New York: Atropos Press, 2013.

Badiou, Alain. Theory of the Subject. Trans. Bruno Bosteels. New York: Continuum, 2009.

Badiou, Alain, and Gilles Haéri. In Praise of Mathematics. Trans. Susan Spitzer. Malden, MA: Polity, 2016.

Badiou, Alain, and Élisabeth Roudinesco. Jacques Lacan, Past and Present: A Dialogue. Trans. Jason E. Smith. New York: Columbia University Press, 2014.

Berto, Francesco. There's Something about Gödel: The Complete Guide to the Incompleteness Theorem. Malden, MA: WileyBlackwell, 2009.

Berto, Francesco, and Matteo Plebani. Ontology and Metaontology: A Contemporary Guide. New York: Bloomsbury, 2015.

Bosteels, Bruno. Badiou and Politics. Durham: Duke University Press, 2011.

Canguilhem, Georges. A Vital Rationalist: Selected Writings of Georges Canguilhem. Ed. François Delaporte. Trans. Arthur Goldhammer. New York: Zone Books, 2000.

Canguilhem, Georges. Knowledge of Life. Ed. Paola Marrati and Todd Meyers. Trans. Stefanos Geroulanos and Daniela Ginsburg. New York: Fordham University Press, 2008.

Carnap, Rudolf. “The Elimination of Metaphysics Through Logical Analysis of Language.” Trans. Arthur Pap. In Logical Positivism, ed. A. J. Ayer (New York: Free Press, 1959), 60-81.

Carnap, Rudolf. “Logical Foundations of the Unity of Science.” In International Encyclopedia of Unified Science: Volume I, ed. Otto Neurath, Rudolf Carnap, and Charles W. Morris (Chicago: University of Chicago Press, 1938), 42-62.

Carnap, Rudolf. Meaning and Necessity: A Study in Semantics and Modal Logic. Chicago: University of Chicago Press, 1956.

Cassin, Barbara. "Ab-sense, or Lacan from A to D." In Alain Badiou and Barbara Cassin, There's No Such Thing as a Sexual Relationship: Two Lessons on Lacan, trans. Susan Spitzer and Kenneith Reinhard (New York: Columbia University Press, 2017), 3-43

Coffa, J. Alberto. The Semantic Tradition from Kant to Carnap. New York: Cambridge University Press, 1991.

Davidson, Donald. "The Method of Truth in Metaphysics." In Inquiries into Truth and Interpretation, 2nd ed. (New York: Oxford University Press, 2001), 199-214.

Davidson, Donald. “On the Very Idea of a Conceptual Scheme.” In Inquiries into Truth and Interpretation, 2nd ed. (New York: Oxford University Press, 2001), 183-98.

Davidson, Donald. “Radical Interpretation." In Inquiries into Truth and Interpretation, 2nd ed. (New York: Oxford University Press, 2001), 125-39.

Davidson, Donald. “True to the Facts." In Inquiries into Truth and Interpretation, 2nd ed. (New York: Oxford University Press, 2001), 37-54.

Davidson, Donald. “Truth and Meaning." In Inquiries into Truth and Interpretation, 2nd ed. (New York: Oxford University Press, 2001), 17-36.

Davidson, Donald. Truth and Predication. Cambridge: Harvard University Press, 2005.

Dummett, Michael. Frege: Philosophy of Language. 2nd ed. Cambridge: Harvard University Press, 1981.

Dummett, Michael. Origins of Analytical Philosophy. Cambridge: Harvard University Press, 1994.

Dummett, Michael. “Truth.” Proceedings of the Aristotelian Society 59.1 (1959): 141-62.

Earman, John. “Carnap, Kuhn, and the Philosophy of Scientific Methodology.” In World Changes: Thomas Kuhn and the Nature of Science, ed. Paul Horwich (Cambridge: MIT Press, 1993), 9-36.

Fink, Bruce. The Lacanian Subject: Between Language and Jouissance. Princeton: Princeton University Press, 1995.

Frege, Gottlob. The Basic Laws of Arithmetic: Exposition of the System. Ed. and trans. Montgomery Furth. Berkeley and Los Angeles: University of California Press, 1967.

Frege, Gottlob. “Boole's Logical Calculus and the Concept-Script.” In Posthumous Writings, ed. Hans Hermes, Friedrich Kambartel, and Friedrich Kaulbach, trans. Peter Long and Roger White (Chicago: University of Chicago Press, 1979), 9-46. 
Frege, Gottlob. The Foundations of Arithmetic. 2nd rev. ed. Trans. J. L. Austin. Evanston: Northwestern University Press, 1980.

Frege, Gottlob. "Function and Concept." In Collected Papers on Mathematics, Logic, and Philosophy, ed. Brian McGuinness, trans. Max Black et al (New York: Basil Blackwell, 1984), 137-56

Frege, Gottlob. “Logical Investigations." In Collected Papers on Mathematics, Logic, and Philosophy, ed. Brian McGuinness, trans. Max Black et al (New York: Basil Blackwell, 1984), 351-406.

Frege, Gottlob. “Notes for Ludwig Darmstaedter." In Posthumous Writings, ed. Hans Hermes, Friedrich Kambartel, and Friedrich Kaulbach, trans. Peter Long and Roger White (Chicago: University of Chicago Press, 1979), 253-57.

Frege, Gottlob. “On Concept and Object." In Collected Papers on Mathematics, Logic, and Philosophy, ed. Brian McGuinness, trans. Max Black et al (New York: Basil Blackwell, 1984), 182-94.

Frege, Gottlob. "On Sense and Meaning." In Collected Papers on Mathematics, Logic, and Philosophy, ed. Brian McGuinness, trans. Max Black et al (New York: Basil Blackwell, 1984), 157-77.

Frege, Gottlob. Philosophical and Mathematical Correspondence. Ed. Gottfried Gabriel et al. Trans. Hans Kaal. Chicago: University of Chicago Press, 1980.

Gabriel, Gottfried, and Wolfgang Keinzler, eds. "Diary: Written by Professor Dr. Gottlob Frege in the Time from 10 March to 9 April 1924.” Trans. Richard L. Mendelsohn. Inquiry 39 (1996): 303-42.

Glock, Hans-Johann. What Is Analytic Philosophy? New York: Cambridge University Press, 2008.

Hahn, Hans, Otto Neurath, and Rudolf Carnap. "Wissenschaftliche Weltauffassung: Der Wiener Kreis [The Scientific Conception of the World: The Vienna Circle]." In Otto Neurath, Empiricism and Sociology, ed. Marie Neurath and Robert S. Cohen (Boston: D. Reidel Publishing, 1973), 299-318.

Hallward, Peter. Badiou: A Subject to Truth. Minneapolis: University of Minnesota Press, 2003.

Hallward, Peter, and Knox Peden, eds. Concept and Form. 2 vols. New York: Verso, 2012.

James, William. The Principles of Psychology. 2 vols. New York: Dover Publications, 1950.

Johnston, Adrian. Prolegomena to Any Future Materialism, Volume One: The Outcome of Contemporary French Philosophy. Evanston, IL: Northwestern University Press, 2013.

Kuhn, Thomas S. “Commensurability, Comparability, Communicability.” In The Road Since Structure: Philosophical Essays, 1970-1933, with an Autobiographical Interview, ed. James Conant and John Haugeland (Chicago: University of Chicago Press, 2000), 33-57.

Lewis, William S. Louis Althusser and the Traditions of French Marxism. New York: Lexington Books, 2005.

Livingston, Paul M. Philosophy and the Vision of Language. New York: Routledge, 2008.

Miller, Jacques-Alain. "Suture." Trans. Zachary Luke Fraser and Ray Brassier. In Concept and Form: Key Texts from the "Cahiers pour l'Analyse”, 2 vols., ed. Peter Hallward and Knox Peden (New York: Verso, 2012), 1:91-101.

Milne, Peter. "Frege's Folly: Bearerless Names and Basic Law V." In The Cambridge Companion to Free, ed. Michael Potter and Tom Ricketts (New York: Cambridge University Press, 2010), 465-508.

Nagel, Ernest, and James R. Newman. Gödels Proof. New York: New York University Press, 1958.

Plato. Parmenides. Trans. Mary Louise Gill and Paul Ryan. In Plato: Complete Works, ed. John M. Cooper (Indianapolis: Hackett Publishing, 1997), 359-97.

Pluth, Ed. Badiou: A Philosophy of the New. Malden, MA: Polity, 2010.

Quine, W. V. O. "On What There Is." In Quintessence: Basic Readings from the Philosophy of W. V. Quine, ed. Roger F. Gibson, Jr. (Cambridge: Harvard University Press, 2004), 177-92.

Quine, W. V. O. “Two Dogmas of Empiricism.” In Quintessence: Basic Readings from the Philosophy of W. V. Quine, ed. Roger F. Gibson, Jr. (Cambridge: Harvard University Press, 2004), 31-53

Quine, W. V. O. Word and Object. Cambridge: MIT Press, 1960.

Rancière, Jacques. Althusser's Lesson. Trans. Emiliano Battista. New York: Continuum, 2011.

Reck, Erich H., and Steve Awodey, eds. Frege's Lectures on Logic: Carnap's Student Notes, 1910-1914. Trans. Erich H. Reck and Steve Awodey. Chicago and LaSalle, IL: Open Court, 2004.

Russell, Bertrand. “The Philosophy of Logical Atomism.” In Logic and Knowledge (New York: Routledge, 1997), 321-43.

Soames, Scott. Philosophical Analysis in the Twentieth Century. 2 vols. Princeton: Princeton University Press, 2003.

Soames, Scott. "The Place of Willard Van Orman Quine in Analytic Philosophy." In "Analytic Philosophy in America," and Other Historical and Contemporary Essays (Princeton: Princeton University Press, 2014), 104-38.

Spencer, Joseph M. "Formalism and the Notion of Truth.” Ph.D. dissertation, University of New Mexico, 2015.

Tarski, Alfred. “The Concept of Truth in Formalized Languages.” In Logic, Semantics, Metamathematics, 2nd ed., ed. John Corcoran, trans. J. H. Woodger (Indianapolis: Hackett Publishing, 1983), 152-278.

Tarski, Alfred. Introduction to Logic and to the Methodology of Deductive Sciences. New York: Dover Publications, 1995.

Tarski, Alfred. "The Semantic Conception of Truth, and the Foundations of Semantics." Philosophy and Phenomenological Research 4.3 (March 1944): 341-76.

Tho, Tzuchien, and Giuseppe Bianco, eds. Badiou and the Philosophers: Interrogating 1960s French Philosophy. Trans. Tzuchien Tho and Giuseppe Bianco. New York: Bloomsbury, 2013.

Weiner, Joan. Frege. New York: Oxford University Press, 1999.

Weiner, Joan. Frege in Perspective. Ithaca: Cornell University Press, 1990. 
Wheeler, Samuel C., III. “Davidson, Derrida, and Difference.” In Dialogues with Davidson: Acting, Interpreting, Understanding, ed. Jeff Malpas (Cambridge: MIT Press, 2011), 29-42.

Wolin, Richard. The Wind from the East: French Intellectuals, the Cultural Revolution, and the Legacy of the 1960s. Princeton: Princeton University Press, 2010.

Wrathall, Mark A. "The Conditions of Truth in Heidegger and Davidson." In Heidegger and Unconcealment: Truth, Language, and History (New York: Cambridge University Press, 2011), 40-56. 